\title{
Trans-Activation Response Element RNA is Detectable in the Plasma of a Subset of Aviremic HIV-1-Infected Patients
}

\author{
Anžej Hladnik, ${ }^{1}$ Jana Ferdin, ${ }^{1}$ Katja Goričar, ${ }^{1}$ Steven G. Deeks, ${ }^{2}$ \\ Boris M. Peterlin, ${ }^{2}$ Ana Plemenitaš, ${ }^{1}$ Vita Dolžan ${ }^{1}$ and Metka Lenassi ${ }^{1}{ }^{1 *}$ \\ ${ }^{1}$ Institute of Biochemistry, Faculty of Medicine, University of Ljubljana, Ljubljana, Slovenia \\ ${ }^{2}$ Department of Medicine, University of California, San Francisco (UCSF), San Francisco, California, USA \\ * Corresponding author: E-mail: metka.lenassi@mf.uni-lj.si \\ Tel: +386-1-5437658; Fax: +386-1-5437641
}

Received: 31-08-2016

For Cutting Edge 2017

\begin{abstract}
Determining the HIV-1 reservoir size in infected individuals is of great importance for improvement of their treatment. Plasma trans-activation response element (TAR) RNA has been suggested as one of the possible biomarkers. TAR RNA is produced during non-processive transcription in HIV-1 productively infected and latent T cells. Here, plasma samples and paired exosome samples of 55 subjects from the observational SCOPE cohort were analysed for the presence of TAR RNA. First, a PCR-based assay was optimized, which provided 100\% specificity and $100 \%$ sensitivity in differentiating HIV-1 infected non-controllers from uninfected individuals. Next, TAR RNA was detected in the plasma of $63 \%$ of aviremic HIV-1-infected patients, who were either treated with antiretroviral therapy or were elite controllers. Although TAR RNA levels did not correlate with patient gender, age, CD4 levels, CD8 levels, they tended to correlate with $\mathrm{CD} 4 / \mathrm{CD} 8$ ratio $(\mathrm{P}=0.047)$. This study is the first to investigate plasma TAR RNA in a relatively large cohort of HIV1 -infected patients. We additionally show that the TAR RNA molecules in the plasma of aviremic patients are not limited to exosomes.
\end{abstract}

Keywords: HIV-1, trans-activation response element, exosomes, latency, HIV-1 reservoir, miRNA

\section{Introduction}

HIV remains a major global public health issue, and the World Health Organisation has estimated that around 36.7 million people were infected at the end of 2015. In the majority of HIV-1-infected patients, the combination antiretroviral therapy (ART) reduces plasma HIV-1 RNA to clinically undetectable levels. However, this treatment cannot eradicate proviruses hidden in CD4 T cells and other latent reservoirs. ${ }^{1}$ Over $90 \%$ of these proviruses are believed to be defective, such that they cannot produce intact viruses, ${ }^{2}$ although they were recently shown to produce novel protein-encoding RNA species. ${ }^{3}$ These might contribute to chronic inflammation, which together with antiretroviral drug toxicity and the traditional risk factors, might promote increased risk of developing non-
AIDS-associated diseases in ART-treated adults (e.g., cardiovascular, liver, renal and bone diseases, cancers). ${ }^{4-6}$ Thus, determination of the size of the HIV-1 reservoir in aviremic individuals is important for the understanding of HIV pathogenesis and to adjust the therapy to improve the quality of life of the patient.

One potential biomarker of the patient HIV-1 reservoir is the transactivation-response element (TAR) RNA and its micro RNAs, hiv-1-miR-TAR-3p and hiv-1-miRTAR-5p. The 57-nucleotide TAR hairpin structure is part of the long terminal repeat promoter of the HIV genome (Figure 1A). This acts as a binding site for the viral-encoded transactivator protein Tat, which is important for induction of transcription of full-length viral mRNAs during productive infection (i.e., processive transcription). In the absence of Tat during latency, transcription is lar- 
gely non-processive, which results in the release of short RNAs that include the TAR region (Figure 1B). ${ }^{7}$ In infected primary $\mathrm{T}$ lymphocytes and latently infected cell lines, these short TAR RNAs are processed by Dicer to yield hiv-1-miR-TAR-3p, and to a lesser extent also hiv-1-miRTAR-5p. ${ }^{8-12}$ HIV TAR miRNAs target and modulate the expression of several T-cell mRNAs that are involved in apoptosis resistance of HIV-1-infected cells. ${ }^{13,14}$ They can also repress viral gene expression through transcriptional silencing in HIV-1-infected 293 cells $^{8}$ and human primary macrophages ${ }^{15}$ thereby contributing to viral latency.

Importantly, TAR RNA and miR-TARs are released from HIV-1-infected cells within exosomes, which have a putative role in decreasing apoptosis and increasing sus- ceptibility to HIV-1 infection of recipient T cells, ${ }^{16}$ and increasing release of proinflammatory cytokines from recipient macrophages. ${ }^{12,17}$ TAR-RNA-containing exosomes have also been detected in the serum of a small number of aviremic HIV-1-infected patients. ${ }^{12,16,17}$ Exosomes are nano-sized membrane vesicles that are secreted by fusion of multivesicular bodies with the plasma membrane of the cell. They are released from cells in culture in vitro and are found in various body fluids in vivo, like blood plasma, cerebrospinal fluid, urine, and others (reviewed in Thery et al. ${ }^{18}$ ). Exosomes consist of a lipid bilayer membrane that surrounds a small amount of cytosol, and they contain various typical proteins, lipids and nucleic acids, which mirror the composition of the cell of origin. ${ }^{19}$ Exo- a)

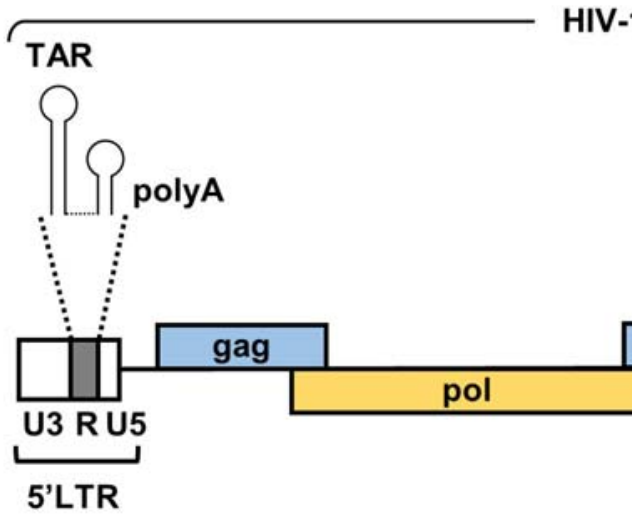

HIV-1 RNA genome

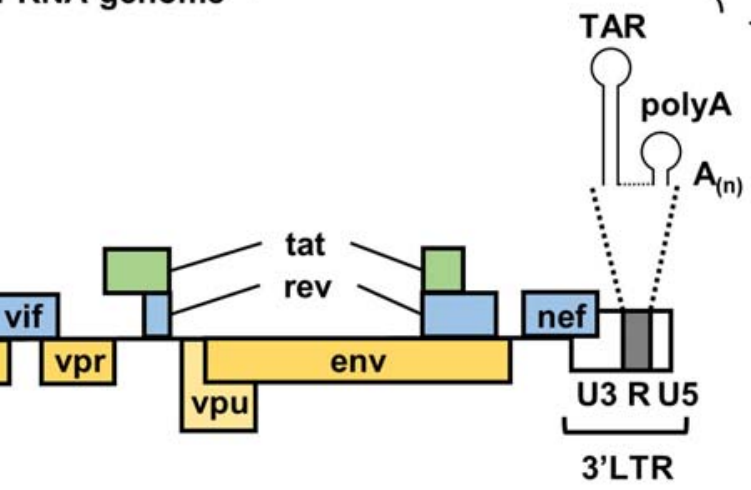

Non-processive /

+ Tat

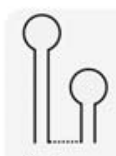

$\{?$
Productive

HIV-1 infection processive transcription

Non-processive transcription

HIV-1 latency

- Tat

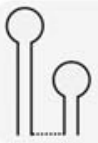

b)

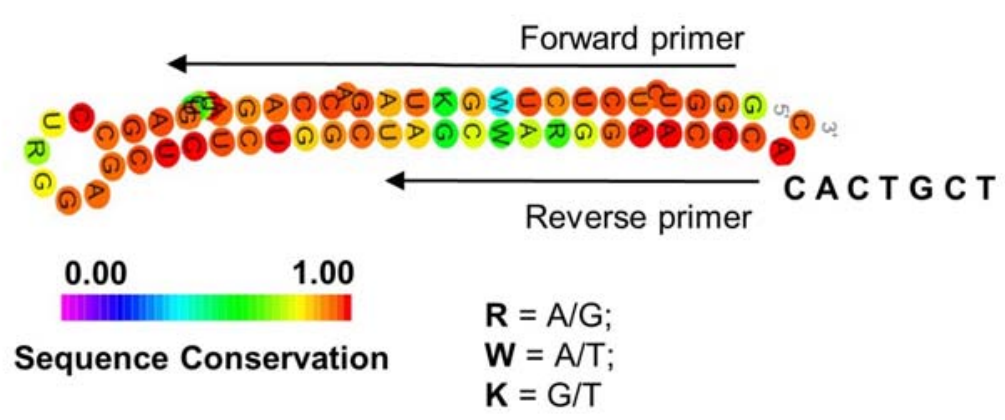

TAR RNA

Figure 1. TAR as part of the HIV-1 provirus, HIV-1 genome, and TAR RNA. (a) Scheme of the HIV-1 genome (modified from Harwig et al. ${ }^{11}$ ), showing the long terminal repeat (LTR) region divided into the U3, R (including TAR) and U5 domains. In the presence of Tat (+Tat), full-length viral RNA and short TAR RNA molecules are transcribed, while in the absence of Tat (-Tat), only TAR RNA is produced. (b) Structure and sequence conservation of the TAR hairpin (57 nucleotides) with the indicated oligonucleotides used for the specific amplification of TAR RNA. 
somes have an important role in physiological processes and various pathological conditions, ${ }^{20-22}$ including HIV pathogenesis, ${ }^{23,24}$ and thus have promising potential for human diagnostics and therapeutic applications. ${ }^{25}$

The aim of the present study was to determine whether TAR RNA can be found in the blood plasma of aviremic HIV-1-infected patients in a relatively large cohort, and to examine whether detection of TAR RNA correlates to patient clinical characteristics. To this end, a TAR-specific PCR assay was first optimised on uninfected controls and viral non-controllers, with determination of its specificity and sensitivity. Next, plasma TAR-RNA levels were determined in a cross-sectional study of ART-suppressed patients and elite controllers.

\section{Experimental}

\section{1. Subjects}

This study was based on 55 plasma samples from the Observational Study of the Consequences of the Protease Inhibitor Era (SCOPE) cohort, which were collected from well-characterised HIV-infected volunteers of diverse demographic and clinical status at the HIV/AIDS clinic of the San Francisco General Hospital, following protocols approved by the University of California, San Francisco, Committee on Human Research. All of the subjects provided written informed consent.

In brief, whole blood samples were collected in commercially available EDTA-treated tubes and processed by low-speed centrifugation $(2000 \times g, 15 \mathrm{~min})$ within $2 \mathrm{~h}$, with the supernatants aliquoted, frozen, and stored at $-70{ }^{\circ} \mathrm{C}$. The study subjects were stratified into four groups: (i) HIV-1 uninfected subjects ('HIV negative'; $\mathrm{n}=$ 9); (ii) 'non-controllers' ( $\mathrm{n}=8$ ), as HIV-1-infected patients who had never been treated with ART; (iii) ARTtreated virologic controllers ('ART-suppressed'; $\mathrm{n}=19$ ), as HIV-1-infected patients with undetectable plasma HIV RNA levels for at least 6 months while treated with ART; and (iv) spontaneous virologic controllers ('elite controllers'; $\mathrm{n}=19$ ), as untreated HIV-infected patients who had shown at least three documented plasma HIV RNA levels $<75$ copies/mL over at least a 12 -month period. The clinical characteristics of these patients are given in Table 1.

\section{2. RNA Extraction from Plasma and Plasma Exosomes}

Initially, the plasma samples $(1 \mathrm{~mL})$ were slowly defrosted on ice (i.e., approximately $1 \mathrm{~h}$ at $4{ }^{\circ} \mathrm{C}$ ) and centrifuged $(2000 \times \mathrm{g}, 30 \mathrm{~min})$ to remove precipitated lipids and any remaining white blood cells and platelets. The TRIzol nucleic acid extraction reagent (Invitrogen) was added to an aliquot $(200 \mu \mathrm{L})$ of each plasma sample, which were then mixed well and stored at $-70{ }^{\circ} \mathrm{C}$ until further proces- sing. The rest of the plasma of each sample was filtered through a $0.45-\mu \mathrm{m}$ membrane (Millipore), diluted threefold with Dulbecco's phosphate-buffered saline, and centrifuged $(110,000 \times g, 2 \mathrm{~h}$; SW-41 Ti rotor) on a $20 \%$ sucrose cushion, to purify the exosomes. The pelleted exosomes, and in the case of the non-controllers also the viruses, were resuspended in Dulbecco's phosphate-buffered saline, after which TRIzol nucleic acid extraction reagent was added, and the samples were stored at $-70{ }^{\circ} \mathrm{C}$ until further processing.

For the extraction of small non-coding RNA from these processed samples, a combination of TRIzol RNA extraction and spin column miRNA enrichment was used, as described previously by Valadi et al. ${ }^{26}$ First, the RNA extraction with TRIzol (Invitrogen) was carried out following the manufacturer guidelines, until the phase separation by chloroform, after which the upper aqueous phase of each sample was transferred to RNeasy spin columns (miRNeasy mini kits; Qiagen), and the manufacturer instructions were followed. In the last step, the enriched small non-coding RNA was eluted from the columns with $50 \mu \mathrm{L}$ RNase-free water with centrifugation at $15,000 \times g$ for $2 \mathrm{~min}$.

\section{3. TAR-RNA-specific Reverse-transcription}

Gene-specific cDNA for TAR RNA was generated using SuperScript IV Reverse Transcriptase kits (Invitrogen) and the TAR-specific reverse primer (TAR-R [+42 - +62]: 5'- AGC AGT GGG TTC CCT AGT TAG 3'; Figure 1B), following the manufacturer instructions. In brief, each single $10 \mu \mathrm{L}$ reverse transcription reaction started with $0.5 \mu \mathrm{L} 10 \mathrm{mM}$ dNTP mix, $1 \mu \mathrm{L} 2 \mu \mathrm{M}$ TAR-R [+42 - +62] primer, $2.5 \mu \mathrm{L}$ RNase free $\mathrm{H}_{2} \mathrm{O}$, and $2 \mu \mathrm{L}$ plasma / exosomes RNA, combined as a volume of $6 \mu \mathrm{L}$. This RNA-primer mix was heated at $65^{\circ} \mathrm{C}$ for $5 \mathrm{~min}$, and then incubated on ice for at least $1 \mathrm{~min}$. Next, the following additions were made to the RNA-primer mixture: 2 $\mu \mathrm{L} 5 \times$ SSIV Buffer, $0.5 \mu \mathrm{L} 100 \mathrm{mM}$ 1,4-dithiothreitol, 1 $\mu \mathrm{L}$ ribonuclease inhibitor (RNaseOUT, $40 \mathrm{U} / \mu \mathrm{L}$; Invitrogen) and $0.5 \mu \mathrm{L}$ SuperScript IV Reverse Transcriptase (200 U/ $\mu \mathrm{L}$; Invitrogen). This total mixture of $10 \mu \mathrm{L}$ was then incubated at $55^{\circ} \mathrm{C}$ for $10 \mathrm{~min}$, heat inactivated at 80 ${ }^{\circ} \mathrm{C}$ for $10 \mathrm{~min}$, and stored at $-20{ }^{\circ} \mathrm{C}$.

\section{4. TAR-specific PCR Detection}

PCR analysis was performed using two different polymerase systems: ExiLENT SYBR Green master mix (Exiqon), and GoTaq Green master mix (Promega). The PCR reaction mixture of $25 \mu \mathrm{L}$ contained: $5 \mu \mathrm{L}$ TAR-specific cDNA (diluted 5-fold in DNase free $\mathrm{H}_{2} \mathrm{O}$ ), $12.5 \mu \mathrm{L}$ $2 \times$ PCR master mix, $5 \mu \mathrm{L}$ DNase-free $\mathrm{H}_{2} \mathrm{O}$, and $2.5 \mu \mathrm{L}$ $10 \mu \mathrm{M}$ TAR-primer mix (TAR-R [+42 - +62]: 5'- AGCAGTGGGTTCCCTAGTTAG -3'; TAR-F: 
5'-GGTCTCTCTGGTTAGACC-3'). The PCR amplification started with denaturation at $95^{\circ} \mathrm{C}$ for $2 \mathrm{~min}$, followed by 40 amplification cycles of $30 \mathrm{~s}$ at $95^{\circ} \mathrm{C}, 30 \mathrm{~s}$ at $60^{\circ} \mathrm{C}$, and $30 \mathrm{~s}$ at $72{ }^{\circ} \mathrm{C}$. After amplification, the PCR-products were resolved in 5\% agarose gels containing ethidium bromide, which were run at $110 \mathrm{~V}$ in TBE buffer. Finally, the TAR-specific PCR-product was documented by MiniBis (DNR BioImaging Systems, Biosciences). For samples, where TAR-specific PCR-product was not detected, the PCR was repeated on undiluted TAR-specific cDNA ( $2.5 \mu \mathrm{L}$ per $25 \mu \mathrm{L}$ reaction).

\section{5. Statistical Analysis}

Median and interquartile ranges or frequencies were used to describe continuous or categorical variables. Mann-Whitney tests or Fisher's exact tests were used to compare clinical characteristics among groups with differing TAR expression. Statistical analysis was performed using IBM SPSS Statistics, version 19.0 (IBM Corporation, Armonk, USA). The level of statistical significance was set at $P<0.05$.

\section{Results and Discussion}

Determination of the HIV-1 reservoir size in infected individuals is of great importance for the improvement of their treatment, and plasma TAR RNA might serve as one such biomarker. TAR RNA was previously detected in two sera and sera-exosome-enriched samples from avire- mic ART-suppressed patients and elite controllers, ${ }^{16}$ and in an additional four sera exosome-enriched samples from aviremic ART-suppressed patients. ${ }^{17}$ However, to date, plasma TAR-RNA levels have never been tested on a larger cohort of HIV-1-infected patients. In the present study, plasma samples and paired exosome samples of 55 subjects from the SCOPE cohort were analysed for the presence of TAR RNA. The clinical characteristics of these patients are given in Table 1.

First, the TAR-specific PCR-based assay was optimised using the samples from the uninfected controls ( $\mathrm{n}=$ $9)$ and the viral non-controllers $(n=8)$, which were expected to test negative and positive for TAR RNA, respectively. In our hands, the previously used method for TAR RNA detection with quantitative PCR has not worked correctly ${ }^{17}$ with non-specific products identified using melting curve analysis. Therefore, traditional PCR amplification was performed using TAR-specific oligonucleotides binding to TAR-specific reverse transcribed cDNA, and the ExiLENT SYBR Green or GoTaq Green master mixes (Figure 1B). To improve resolution, the PCR products were separated on 5\% agarose gels and revealed by ethidium bromide. For the non-controllers, both of these master mixes typically amplified a 64-bp-long TAR-specific PCR product, plus one or more smaller unspecific PCR products, which probably represented oligonucleotide dimers (Supplementary Figure 1). The identity of the TAR-specific product was confirmed by DNA sequencing (data not shown). An individual was declared TAR RNA positive if one of the DNA polymerase PCR assays (i.e., with ExiLENT or GoTaq) amplified a specific TAR product from

Table 1: Clinical characteristics of the study participants.

\begin{tabular}{|c|c|c|c|c|}
\hline \multirow{2}{*}{$\begin{array}{l}\text { Clinical } \\
\text { characteristic }\end{array}$} & \multicolumn{4}{|c|}{ Patient group } \\
\hline & HIV negative & Non-controllers & ART-suppressed & Elite controllers \\
\hline$\overline{\text { Gender [n (\%)] }}$ & $9(100)$ & $8(100)$ & $19(100)$ & $19(100)$ \\
\hline Male & $8(88.9)$ & $6(75.0)$ & 15 (78.9) & $12(63.1)$ \\
\hline Female & $1(11.1)$ & $0(0.0)$ & $4(21.1)$ & $5(26.3)$ \\
\hline Intersex* & $0(0.0)$ & $1(12.5)$ & $0(0.0)$ & $0(0.0)$ \\
\hline Male to female transgender & $0(0.0)$ & $1(12.5)$ & $0(0.0)$ & $2(10.5)$ \\
\hline $\begin{array}{l}\text { Age (years) } \\
{[\text { median }(25 \%-75 \%)]}\end{array}$ & $\begin{array}{c}52.0 \\
(35.0-59.0)\end{array}$ & $\begin{array}{c}49.5 \\
(40.0-53.8)\end{array}$ & $\begin{array}{c}57.0 \\
(49.0-60.0)\end{array}$ & $\begin{array}{c}50.0 \\
(40.0-55.0)\end{array}$ \\
\hline $\begin{array}{l}\mathrm{CD} 4\left(\text { cells } / \mathrm{mm}^{3}\right) \\
{[\text { median }(25 \%-75 \%)]}\end{array}$ & $\begin{array}{c}738 \\
(397.5-1317.0)\end{array}$ & $\begin{array}{c}401 \\
(254.5-690.8)\end{array}$ & $\begin{array}{c}649 \\
(461.0-721.0)\end{array}$ & $\begin{array}{c}1047 \\
(955.0-1301.0)\end{array}$ \\
\hline 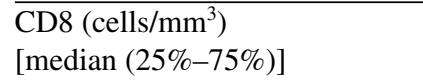 & $\begin{array}{c}443 \\
(261.5-623.5)\end{array}$ & $\begin{array}{c}1662 \\
(1048.8-1850.8)\end{array}$ & $\begin{array}{c}761 \\
(587.0-920.0)\end{array}$ & $\begin{array}{c}734 \\
(490.0-964.0)\end{array}$ \\
\hline $\begin{array}{l}\text { CD4/CD8 ratio } \\
\text { [median }(25 \%-75 \%)]\end{array}$ & $\begin{array}{c}2.28 \\
(1.47-3.03)\end{array}$ & $\begin{array}{c}0.25 \\
(0.21-0.37)\end{array}$ & $\begin{array}{c}0.68 \\
(0.56-0.97)\end{array}$ & $\begin{array}{c}1.51 \\
(1.24-1.99)\end{array}$ \\
\hline $\begin{array}{l}\text { Viral load (copies/mL) } \\
\text { [median }(25 \%-75 \%)]\end{array}$ & 1 & $\begin{array}{c}24146 \\
(19751-36450)\end{array}$ & $<75$ & $<75$ \\
\hline \multicolumn{5}{|l|}{ TAR [n (\%)] } \\
\hline Negative & $9(100.0)$ & $0(12.5)$ & $10(52.6)$ & $4(21.1)$ \\
\hline Positive & $0(0.0)$ & $8(100.0)$ & $9(47.4)$ & 15 (78.9) \\
\hline
\end{tabular}

* Individuals with a reproductive or sexual anatomy that is distinct from that of the typical male or female. 
cDNA from one of the two sample types (i.e., plasma or plasma exosomes) (Table 1, Supplementary Table 1).

Comparison of the HIV-1-negative patients and the non-controllers showed that TAR RNA was detected in 0/9 HIV-negative patients and 8/8 non-controller patients, providing $100 \%$ specificity and $100 \%$ sensitivity. Narayanan et al. ${ }^{16}$ previously showed that TAR RNA is part of the exosomes, not only the viruses, in supernatants of HIV1-infected primary CD4 T-cell cultures. Furthermore, the present analysis was performed on RNA that was enriched for small molecules, like miRNAs. It can therefore be speculated that at least some of the detected TAR molecules in the non-controllers were the TAR RNAs produced by non-processive transcription during their HIV-1 productive infection and latency (Figure 1A), ${ }^{11}$ although the presence of TAR-containing full-length HIV RNA transcripts cannot be excluded.

Next, the detection of TAR RNA in the plasma of HIV-1-infected patients was tested, in terms of those with suppressed plasma HIV-1 RNA levels with the use of ART (i.e., ART-suppressed) or without (elite controllers). The likely source of HIV-1 RNA in these patients would be latently infected cells. ${ }^{11}$ Nine out of 19 ART-suppressed patients and 15/19 elite controllers were positive for TAR RNA (Table 1). In contrast, all of the aviremic HIV-1-infected patients in two previous studies were positive for TAR RNA, ${ }^{16,17}$ although only up to four samples were tested, along with pooled blood sera from six patients, which might well have overridden their true TAR-RNA status. On the other hand, the absence of the TAR-RNA signal in some of the aviremic HIV-1-infected patients studied here might also be due to lower sensitivity of the traditional PCR used in the present study compared to the quantitative PCR used in these previous studies. ${ }^{16,17}$ Among all of the TAR-positive aviremic HIV-1-infected patients $(n=24$; Supplementary Table 1$)$, TAR RNA of exosomal origin was detected in only nine, which implies that TAR RNA was also present outside of exosomes, in the plasma, which is contrary to previous reports. ${ }^{17}$ Alternatively, the freezing and thawing might have impacted on the structural integrity of the exosomes to cause release of TAR RNA into the plasma, although some recent studies reported no or limited effects of plasma freeze-thawing on exosome or exosomal RNA recovery. ${ }^{27,28}$

To better understand which clinical characteristics might be associated with the presence of TAR RNA in the plasma of aviremic HIV-1-infected patients, TAR-negative and TAR-positive patients were compared using MannWhitney and Fisher's exact tests. The presence of TAR RNA in the plasma of these patients did not correlate with patient gender, age, CD4 levels, CD8 levels, but tended to correlate with CD4/CD8 ratio $(P=0.047$, Table 2$)$. CD4 T cells are the primary target of HIV-1, whereby this infection promotes their depletion, although their levels partially recover in patients receiving ART. ${ }^{29}$ The anti-HIV1-specific CD8 $\mathrm{T}$ cells are activated by the CD4 T cells, and they are crucial in the control of viremia, whereby they increase in response to ongoing viral replication. ${ }^{29}$ Interestingly, the CD4 T-cell nadir (i.e., the lowest point to which the CD4 cell count dropped), the CD4/CD8 ratio,

Table 2: Comparison of distribution of clinical characteristics among TAR-negative and TAR-positive aviremic HIV-1-infected patients.

\begin{tabular}{|c|c|c|c|}
\hline \multirow{2}{*}{$\begin{array}{l}\text { Clinical } \\
\text { characteristic }\end{array}$} & \multicolumn{2}{|c|}{ TAR } & \multirow[t]{2}{*}{$P$ value } \\
\hline & Negative & Positive & \\
\hline$\overline{\text { Gender [n }(\%)]}$ & $14(100)$ & $24(100)$ & \\
\hline Male & $11(78.6)$ & $16(66.7)$ & $0.508^{\mathrm{a}}$ \\
\hline Female & $2(14.3)$ & $7(29.2)$ & \\
\hline Male to female transgender & $1(7.1)$ & $1(4.2)$ & \\
\hline $\begin{array}{l}\text { Age (years) } \\
{[\text { median }(25 \%-75 \%)]}\end{array}$ & $\begin{array}{c}57.5 \\
(44.0-61.3)\end{array}$ & $\begin{array}{c}52.0 \\
(42.3-57.5)\end{array}$ & $0.135^{\mathrm{b}}$ \\
\hline $\begin{array}{l}\text { CD4 }\left(\text { cells } / \mathrm{mm}^{3}\right) \\
{[\text { median }(25 \%-75 \%)]}\end{array}$ & $\begin{array}{c}625.5 \\
(486.5-904.0)\end{array}$ & $\begin{array}{c}967.5 \\
(660.0-1090.0)\end{array}$ & $0.067^{\mathrm{b}}$ \\
\hline $\begin{array}{l}\mathrm{CD} 8\left(\text { cells } / \mathrm{mm}^{3}\right) \\
{[\text { median }(25 \%-75 \%)]}\end{array}$ & $\begin{array}{c}869 \\
(644.5-953.5)\end{array}$ & $\begin{array}{c}645 \\
(516.5-905.3)\end{array}$ & $0.330^{b}$ \\
\hline $\begin{array}{l}\text { CD4/CD8 ratio } \\
{[\text { median }(25 \%-75 \%)]}\end{array}$ & $\begin{array}{c}0.71 \\
(0.54-1.49)\end{array}$ & $\begin{array}{c}1.26 \\
(0.86-1.77)\end{array}$ & $0.047^{b}$ \\
\hline $\begin{array}{l}\text { Treatment with protease inhibitor } \\
\text { No } \\
\text { Yes }\end{array}$ & $\begin{array}{l}\text { \%) }]^{\mathrm{c}} \\
5(50.0) \\
5(50.0)\end{array}$ & $\begin{array}{l}4(44.4) \\
5(55.6)\end{array}$ & $1.000^{\mathrm{a}}$ \\
\hline $\begin{array}{l}\text { Treatment with non-nucleoside re } \\
\text { No } \\
\text { Yes }\end{array}$ & $\begin{array}{c}\text { transcriptase i } \\
6(60.0) \\
4(40.0)\end{array}$ & $\begin{array}{l}(\%)]^{\mathrm{c}} \\
7(77.8) \\
2(22.2)\end{array}$ & $0.628^{a}$ \\
\hline
\end{tabular}

${ }^{a}$ calculated using Fisher exact tests; ${ }^{b}$ calculated using Mann-Whitney tests; ${ }^{c}$ only ART-suppressed patients. 
and the CD4 T-cell counts were previously shown to be inversely associated with HIV-1 proviral DNA levels, as one of the measures of the reservoir size. ${ }^{30,31}$

Previous studies have shown that some protease inhibitor treatments can allow low-level viral replication to occur. ${ }^{6,32}$ We therefore compared TAR-RNA levels in patients treated with different ART regimes (Table 2). No differences were observed among the patients who received protease inhibitors compared to patients who did not receive protease inhibitors. On the other hand, in patients who received treatment based on non-nucleoside reverse transcriptase inhibitors, TAR RNA was detected less often, compared to patients who did not receive non-nucleoside reverse transcriptase inhibitors; however this difference did not reach statistical significance (Table 2).

As this study was performed on a limited sample size, further larger studies with better power and with further information on additional clinical characteristics (e.g., inflammatory and reservoir data) are needed to test for correlation of TAR-RNA with CD4/CD8 ratio in HIV1-suppressed patients, and to provide an explanation of the differences in the TAR-RNA levels and the role of ART regimen in these patients. Any influence of genetic polymorphisms that affect ART efficacy ${ }^{33}$ on the plasma TAR levels also needs to be examined.

\section{Conclusions}

In the present study, a PCR-based assay for detection of plasma TAR RNA was initially established. TAR RNA was detected in the plasma samples of $63 \%$ of the aviremic HIV-1-infected patients (i.e., ART-suppressed plus elite controllers), with its source likely to be from non-processive transcription in the HIV-1 latently infected cells, such as the CD4 T cells. The presence of TAR RNA in the plasma tended to correlate only with CD4/CD8 ratio out of the available clinical characteristics of these patients. In addition, this study shows that the TAR RNA molecules in the plasma of aviremic patients are not limited to the exosomes. These findings should be further validated in a study with larger sample size and more detailed patient information.

CONFLICT OF INTEREST: The authors declare that they have no conflicts of interest with the contents of this article.

FUNDING: This study was supported by the Slovenian National Research Agency grants J3-5499, Z3-7198 and P1-0170.

ETHICAL APPROVAL: Written informed consent was obtained from all of the SCOPE cohort participants, and the study was approved by the University of Califor- nia, San Francisco, Committee on Human Research, following Federal Guidelines.

\section{References}

1. N. K. Saksena, S. J. Potter, AIDS Rev. 2003, 5, 3-18.

2. K. M. Bruner, A. J. Murray, R. A. Pollack, M. G. Soliman, S. B. Laskey, A. A. Capoferri, et al., Nat. Med. 2016, 22, 10431049. https://doi.org/10.1038/nm.4156

3. H. Imamichi, R. L. Dewar, J. W. Adelsberger, C. A. Rehm, U. O'Doherty, E. E. Paxinos, et al., Proc. Natl. Acad. Sci. U $S$ A. 2016, 113, 8783-8788.

https://doi.org/10.1073/pnas.1609057113

4. A. N. Phillips, J. Neaton, J. D. Lundgren, AIDS 2008, 22, 2409-2418.

https://doi.org/10.1097/QAD.0b013e3283174636

5. S. G. Deeks, A. N. Phillips, Br. Med. J. 2009, 338, a3172. https://doi.org/10.1136/bmj.a3172

6. H. Hatano, M. C. Strain, R. Scherzer, P. Bacchetti, D. Wentworth, R. Hoh, et al., J. Infect. Dis. 2013, 208, 1436-1442. https://doi.org/10.1093/infdis/jit453

7. M. S. Weinberg, K. V. Morris, DNA Cell Biol. 2006, 25, 223-231. https://doi.org/10.1089/dna.2006.25.223

8. Z. Klase, P. Kale, R. Winograd, M. V. Gupta, M. Heydarian, R. Berro, et al., BMC Mol. Biol. 2007, 8, 63. https://doi.org/10.1186/1471-2199-8-63

9. D. L. Ouellet, I. Plante, P. Landry, C. Barat, M. E. Janelle, L. Flamand, et al., Nucleic Acids Res. 2008, 36, 2353-2365. https://doi.org/10.1093/nar/gkn076

10. N. C. Schopman, M. Willemsen, Y. P. Liu, T. Bradley, A. van Kampen, F. Baas, et al., Nucleic Acids Res. 2012, 40, 414427. https://doi.org/10.1093/nar/gkr719

11. A. Harwig, A. Jongejan, A. H. van Kampen, B. Berkhout, A. T. Das, Nucleic Acids Res. 2016, 44, 4340-4353. https://doi.org/10.1093/nar/gkw167

12. M. A. Bernard, H. Zhao, S. C. Yue, A. Anandaiah, H. Koziel, S. D. Tachado, PLoS One. 2014, 9, e106006. https://doi.org/10.1371/journal.pone.0106006

13. D. L. Ouellet, J. Vigneault-Edwards, K. Letourneau, L. A. Gobeil, I. Plante, J. C. Burnett, et al., Retrovirology. 2013, 10, 86. https://doi.org/10.1186/1742-4690-10-86

14. Z. Klase, R. Winograd, J. Davis, L. Carpio, R. Hildreth, M. Heydarian, et al., Retrovirology. 2009, 6, 18. https://doi.org/10.1186/1742-4690-6-18

15. L. Li, H. Feng, Q. Da, H. Jiang, L. Chen, L. Xie, et al., Arch. Virol. 2016, 161, 1115-1123. https://doi.org/10.1007/s00705-016-2755-5

16. A. Narayanan, S. Iordanskiy, R. Das, R. Van Duyne, S. Santos, E. Jaworski, et al., J. Biol. Chem. 2013, 288, 2001420033. https://doi.org/10.1074/jbc.M112.438895

17. G. C. Sampey, M. Saifuddin, A. Schwab, R. Barclay, S. Punya, M. C. Chung, et al., J. Biol. Chem. 2016, 291, 12511266. https://doi.org/10.1074/jbc.M115.662171

18. C. Thery, S. Amigorena, G. Raposo, A. Clayton, Curr. Protoc. Cell Biol. 2006, Chapter 3, Unit 322. 
19. M. P. Zaborowski, L. Balaj, X. O. Breakefield, C. P. Lai, Bioscience 2015, 65, 783-797. https://doi.org/10.1093/biosci/biv084

20. E. I. Buzas, B. Gyorgy, G. Nagy, A. Falus, S. Gay, Nat. Rev. Rheumatol. 2014, 10, 356-364. https://doi.org/10.1038/nrrheum.2014.19

21. B. Gyorgy, T. G. Szabo, M. Pasztoi, Z. Pal, P. Misjak, B. Aradi, et al., Cell. Mol. Life Sci. 2011, 68, 2667-2688. https://doi.org/10.1007/s00018-011-0689-3

22. J. S. Schorey, S. Bhatnagar, Traffic 2008, 9, 871-881. https://doi.org/10.1111/j.1600-0854.2008.00734.x

23. M. Lenassi, G. Cagney, M. Liao, T. Vaupotic, K. Bartholomeeusen, Y. Cheng, et al., Traffic 2010, 11, 110-122. https://doi.org/10.1111/j.1600-0854.2009.01006.x

24. A. D. Raymond, P. Diaz, S. Chevelon, M. Agudelo, A. Yndart-Arias, H. Ding, et al., J. Neurovirol. 2016, 22, 129139. https://doi.org/10.1007/s13365-015-0397-0

25. B. Gyorgy, M. E. Hung, X. O. Breakefield, J. N. Leonard, Annu. Rev. Pharmacol. Toxicol. 2015, 55, 439-464. https://doi.org/10.1146/annurev-pharmtox-010814-124630

26. H. Valadi, K. Ekstrom, A. Bossios, M. Sjostrand, J. J. Lee, J. O. Lotvall, Nat. Cell Biol. 2007, 9, 654-659. https://doi.org/10.1038/ncb1596

27. M. Jayachandran, V. M. Miller, J. A. Heit, W. G. Owen, J. Immunol. Methods 2012, 375, 207-214. https://doi.org/10.1016/j.jim.2011.10.012

28. Q. Ge, Y. Zhou, J. Lu, Y. Bai, X. Xie, Z. Lu, Molecules 2014, 19, 1568-1575. https://doi.org/10.3390/molecules19021568

29. S. E. Langford, J. Ananworanich, D. A. Cooper, AIDS Res. Ther. 2007, 4, 11. https://doi.org/10.1186/1742-6405-4-11

30. T. W. Chun, J. S. Justement, P. Pandya, C. W. Hallahan, M. McLaughlin, S. Liu, et al., J. Infect. Dis. 2002, 185, 1672 1676. https://doi.org/10.1086/340521

31. M. R. Boulassel, N. Chomont, N. P. Pai, N. Gilmore, R. P. Sekaly, J. P. Routy, J. Clin. Virol. 2012, 53, 29-32. https://doi.org/10.1016/j.jcv.2011.09.018

32. M. J. Buzon, M. Massanella, J. M. Llibre, A. Esteve, V. Dahl, M. C. Puertas, et al., Nat. Med. 2010, 16, 460-465. https://doi.org/10.1038/nm.2111

33. A. V. Coelho, S. P. Silva, L. C. de Alencar, G. Stocco, S. Crovella, L. A. Brandao, et al., J. Clin. Pharmacol. 2013, 53, 1286-1293. https://doi.org/10.1002/jcph.165

\section{Povzetek}

Določitev velikosti rezervoarjev HIV-1 v okuženih posameznikih, lahko pomembno prispeva k izboljšanju njihovega zdravljenja. Eden izmed potencialnih biooznačevalcev za prisotnost rezervoarjev je v plazmi prisoten TAR (angl. transactivation response element) RNA. TAR RNA nastane med ne-procesivnim genskim prepisovanjem v celicah, ki so produktivno ali latentno okužene z virusom HIV-1. V okviru študije smo prisotnost TAR RNA preučevali v vzorcih krvne plazme ter iz nje izoliranih eksosomov 55 oseb iz kohorte SCOPE. Vzpostavili smo metodo detekcije TAR RNA, ki temelji na reakciji PCR, ter z njo s $100 \%$ specifičnostjo ter občutljivostjo ločili nezdravljene viremične bolnike, okužene s HIV-1, od zdravih posameznikov. TAR RNA smo dokazali v plazmi $63 \%$ aviremičnih bolnikov, okuženih s HIV-1, kot so elitni kontrolerji in posamezniki zdravljeni z ART (angl. antiretroviral therapy)). Kljub temu, da prisotnost TAR RNA ni povezana s starostjo, spolom, številom CD4 in CD8 celic, je analiza nakazala na korelacijo z razmerjem celic CD4/CD8 $(P=0,047)$. To je prva študija analize prisotnosti plazemske TAR RNA na razmeroma velikem številu bolnikov, okuženih s HIV-1. Poleg tega smo pokazali, da molekule TAR RNA v plazmi aviremičnih bolnikov niso prisotne zgolj v eksosomih. 